\title{
Integrated Use of AHP-GIS-Remote sensing predicting potential areas of coffee plants: a case study of buffer zone of Ta Dung Nature park, Vietnam
}

\author{
Mai Phuong Pham ${ }^{1, *}$, Dinh Duy $\mathrm{Vu}^{1}$, Thi Hanh Tong ${ }^{2}$, Mai Huong Nguyen Thi ${ }^{3}$ and Robert \\ Sandlersky ${ }^{4}$ \\ ${ }^{1}$ Vietnam - Russia Tropical Central, Cau Giay district, 10000 Ha Noi, Vietnam \\ ${ }^{2}$ Le Quy Don Technical University, Bac Tu Liem district, 10000 Ha Noi, Vietnam \\ ${ }^{3}$ Vietnam National University of Forestry, Chuong My District, 10000 Ha Noi, Vietnam \\ ${ }^{4}$ A.N. Severtsov Institute of Ecology and Evolution, Russian Academy of Sciences, 119071 Moscow, \\ Russia
}

\begin{abstract}
Ta Dung Nature park is an important ecological region, its buffer zone currently has coffee as the main crop. However, declines in coffee yields result in a relative reduction in spending power by households. This study aimed to assess land potential to proposal the land for coffee cultivation. Sustainable agriculture must nurture healthy ecosystems and support the sustainable management of land and natural resources. An approach based on integrated use of the Analytical Hierarchy ProcessGeographic Information Systems and Remote Sensing (AHP-GIS-RS) developed using 13 environmental sub-factors. Study result showed the land of development of current coffee cultivation have had an effect from the most important criteria is soil type (0.24), followed by land use cover unit (0.17) and irrigation system (0.15). Sub-factors ( $\mathrm{SF}_{9}$ : rock expose above soil; $\mathrm{SF}_{11}$ : flood status, $\mathrm{SF}_{12}$ irrigation system) have the largest "potential” land for coffee plants. Coffee plantation was recommended to orient in 6,82\% total of study area by the possibility of expanding cultivated area. A framework of potential model was provided for other industry crops in other study areas in Vietnam.
\end{abstract}

\section{Introduction}

Through the process since coffee seeds are imported into Vietnam. Up to now, development of coffee has not stopped growing. From a country with a rather small initial coffee area, up to now, Vietnam's coffee growing area has increased to over 500,000 hectares [1]. In 1988, Vietnam was only ranked as the fourth largest coffee exporter in the world, until now it has become the world's second producer and exporter. Therefore, coffee trees are evaluated to have an important role and position in the agricultural sector of our country, it has created jobs directly for thousands of people and indirectly for one million workers, contributing to

\footnotetext{
* Corresponding author: phamphuong911vh@gmail.com
} 
poverty reduction, bringing income to many households, especially are ethnic minority households [2].

Ta Dung Nature park of Dak Nong province is an important ecological region, its buffer zone (Dak Som commune: $76.89 \mathrm{~km}^{2}$ ) currently has coffee as the main crop. Six agroforestry land-use models were investigated at the study site, including industrial crops (coffee), pure fruit trees, other perennial crops such as plantation forests, intercropping. The industrial tree (coffee) was the most popular [2]. Study region is considered a very suitable spatial to grow coffee, it is planned, focused on developing and continuously growing, coffee bean products have become the main export commodity of this region. In general, although coffee has brought income to many households, contributing to the annual GDP growth of the province, the quality of coffee is not stable, the competitiveness is poor, and the economic value is reduced. since then, business efficiency of households has also decreased [3, 4]. Climate change will be a reason decrease the coffee production areas around the world [5]. The plants have the most affected by climate change due to their high vulnerability such as droughts, prolonged heat, unseasonal rain, flood $[4,6,7]$. The challenges of local goverment were the establish an integrated approach to the critical areas appropriate urban and territorial planning for human settlements. Beside the deficient researches, planning of the territory to establish potential lands for the cultivation [8], this region has been facing deforestation and forest degradation, land degradation, land conflicts. Further, the poverty rate of the region is relatively high compared to other regions of the country [9, 10]. Land evaluation for plants provides a means of assessing the potential are compared with data from basic surveys (soil, climate, vegetation). The results are assessed on the basis of local area, in economic terms, social sustainability. The requirements of planning are so varied that it is not possible to set out a precise set of procedures, but ten basic stages can be followed FAO [11, 12]. The Analytic Hierarchy Process $[13,14,15]$ is a multiple criterion evaluation methodology that allows the decision makers to decide how much inconsistency is reasonable [16]. The integration of Analytical Hierarchy Process (AHP), Geographic Information Systems (GIS) and Remote Sensing (RS) has been applied in various studies access the land potential for industry crops [17-20]. An approach based on the techniques mentioned above allowed the proper identification of areas with potential for coffee plants in buffer area of Ta Dung Nature park that aims to help the decision manager in making the proper plan.

\section{Materia and method}

\subsection{Data collection}

Instruction for agricultural production land evaluation of Vietnamese Standard TCVN 8409:2012 [21] was used as guide to obtain what kind of data collection for coffee evaluation land potentil, data on many dimensions such as $\mathrm{F}_{1}$ : Temperature ( $\mathrm{SF}_{1}$ : Average annual temperature; $\mathrm{SF}_{2}$ : Annual average minimum temperature; $\mathrm{SF}_{3}$ : Annual average maximum temperature); $\mathrm{F}_{2}$ : Total annual precipitation ( $\mathrm{SF}_{4}$ : Total annual precipitation); $\mathrm{F}_{3}$ : Number of dry months per year $\left(\mathrm{SF}_{5}\right.$ : Number of dry months per year); $\mathrm{F}_{4}$ : Soil characteristics $\left(\mathrm{SF}_{6}\right.$ : Soil type; $\mathrm{SF}_{7}$ : Slope; $\mathrm{SF}_{8}$ : Soil depth; $\mathrm{SF}_{9}$ : Rock exposed above soil; $\mathrm{SF}_{10}$ : Soil composition); $\mathrm{F}_{5}$ : Flood status ( $\mathrm{SF}_{11}$ : Flood status); $\mathrm{F}_{6}$ : Irrigation system ( $\mathrm{SF}_{12}$ Irrigation system); $\mathrm{F}_{7}$ : Currently land unit ( $\mathrm{SF}_{13}$ : Currently land unit). Climatic data collection ( $\mathrm{SF}_{1}$ to $\mathrm{SF}_{5}$ ) was download on https://worldclim.org/data/ and changed to WGS84. Soil map ( $1: 25.000)$ from Ministry of Natural Resources and Environment of Vietnam used to export the data of $\mathrm{SF}_{6}$ to $\mathrm{SF}_{10}$. Some interviewers with local people was be held during the survey to obtain Flood status $\mathrm{SF}_{11}$, Irrigation system $\mathrm{SF}_{12}$. Map of currently land unit of the province by the Ministry of Natural Resources and Environment announced in 2015 used to export the 
land type unit map of study area SF $_{14}$. Landsat 8 (10 March 2021) was obtained from https://glovis.usgs.gov/ used to proposed the map of currently coffee land.

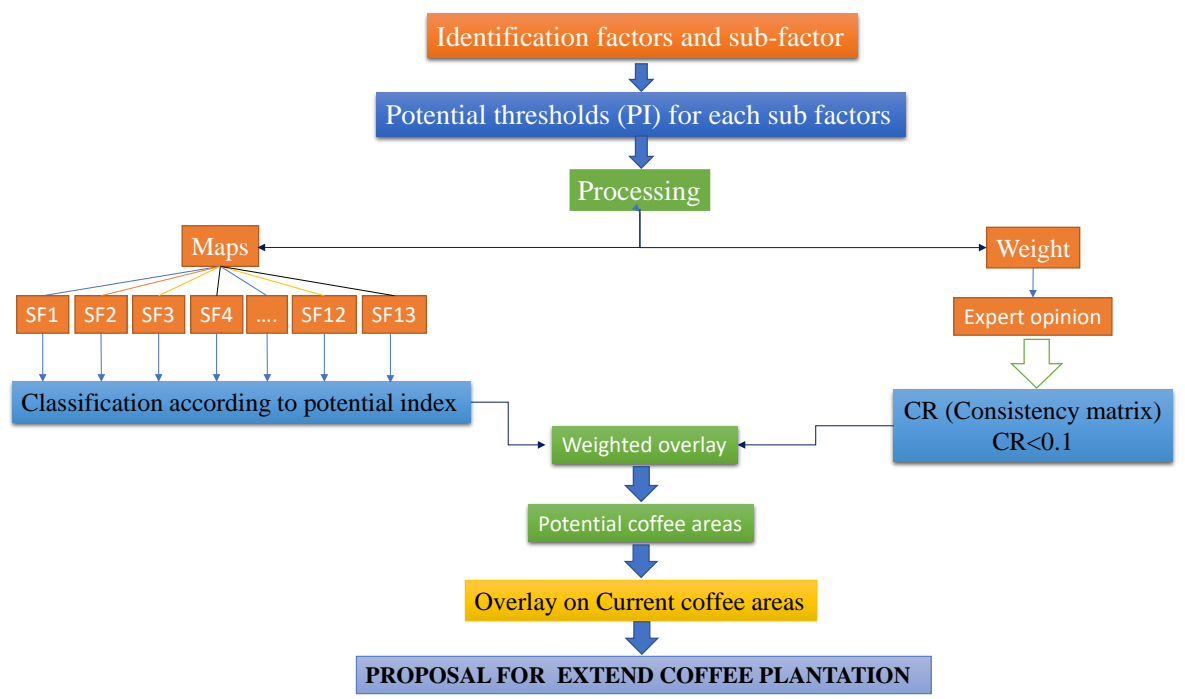

Fig. 1. Steps for the analysis of the potential of the territory for coffee plants in buffer zone of Ta Dung Nature park

\subsection{AHP technology}

The Analytic Hierarchy Process (AHP) is a decision-making support method for selecting a solution from alternatives based on a number of evaluation criteria. Study use this method to solve complex decision-making processes which are structured in hierarchies. A focus group decision (FGDs) was implemented to provide these questionnaires was completed by experts to weight the important of factors and sub-factors using scale in Table 1 . $\mathrm{X}$ is sub-factors that was involded in the classification of potential threshold (PI) using categories in Table 2, $\mathrm{n}$ is number of sub-factors, $n$ in range $(i, j)=(1,13)$.

Table 1. Weighting scale used in AHP [13]

\begin{tabular}{|c|l|l|}
\hline Intensity & \multicolumn{1}{|c|}{ Definition } & \multicolumn{1}{c|}{ Remarks } \\
\hline 1 & Equal importance & $\mathrm{Xi}$ is as importance as $\mathrm{Xj}$ \\
\hline 3 & Weak importance & $\mathrm{Xi}$ is slightly favored over $\mathrm{Xj}$ \\
\hline 5 & Essential importance & $\mathrm{Xi}$ is moderately favored over $\mathrm{Xj}$ \\
\hline 7 & Demonstrated importance & $\mathrm{Xi}$ is strongly favored over $\mathrm{Xj}$ \\
\hline 9 & Absolute importance & $\mathrm{Xi}$ is most strongly preferred over $\mathrm{Xj}$ \\
\hline $2,4,6,8$ & Intermediate & $\begin{array}{l}\text { When a compromise is needed values between } \\
\text { judgments are used }\end{array}$ \\
\hline
\end{tabular}

Each participant in FGDs will provide the weight of each criteria (Table 2). The final score was the average of scores of participants. The experts are five people who work in specialist on agricultural field in Vietnam. In case of the responses to the questionnaire inconsistent, the council will be implemented again to restructure the questionnaire. Alternative of categories of potential index for growing of coffee tree also were restructure to be unity if needed. A true Consistency Ratio is calculated by dividing the Consistency 
Index for the set of judgments by the Index for the corresponding random matrix. Saaty suggests that if that ratio exceeds 0.1 the set of judgments may be too inconsistent to be reliable [13-16, 22].

\subsection{Remote sensing technology}

For land use classification, a supervised classification method was applied using Fracdim (MSU). Landsat 8 provides a source for monitoring coffee land cover using texture features as the indicators. Using mathematical formulas (algorithms) transformed raw satellite data about these light waves into vegetation indices which showed the spatial distribution of identifiable features and provides an informative description of a given area. As a result, the image is partitioned into some non-intersecting regions, such that each region is homogeneous and the union of two adjacent regions is heterogeneous.

\subsection{GIS method}

Weights of 13 sub-factor (i=13) using Expert Choice AHP Software based on the final results of focus group discussion. Maps of evaluation of sub-factors with classification according potential index (PI) by ArcMap 10.0 [11, 12, 23]. Final map was an integration of above maps. The FAO guidelines recommend the use of the same scheme of suitability classification described in the Framework for Land Evaluation. There are four levels of classification of increasing detail: Class $\mathrm{PI}_{1}$ is highly potential; Class $\mathrm{PI}_{2}$ is moderately potential; Class $\mathrm{PI}_{3}$ is marginally potential; Class $\mathrm{N}$ is not potential. Score for each land mapping unit (LMU) was determined using the formula in Eq (1). W is the weigh of each sub-factor used in process, $\mathrm{X}$ is score of each sub-factor according to Instruction for agricultural production land evaluation of Vietnamese Standard TCVN 8409:2012 (Table 3).

$$
\mathrm{PI}=\sum_{i=1}^{n}\left(W_{i} \cdot \mathrm{X}_{\mathrm{i}}\right)
$$

Table 2. Categories of land potential index

\begin{tabular}{|l|l|c|}
\hline Categories of land potential & \multicolumn{1}{|c|}{ Explanation } & Score \\
\hline $\begin{array}{l}\mathbf{P I}_{1}: \text { Potential index 1 (highly } \\
\text { suitable) }\end{array}$ & $\begin{array}{l}\text { Land unit is very favourable for coffee tree and } \\
\text { there are not any limitations of ecological } \\
\text { requirements }\end{array}$ & $>80$ \\
\hline $\begin{array}{l}\mathbf{P I}_{2}: \text { Potential index } 2 \\
\text { (moderately suitable) }\end{array}$ & $\begin{array}{l}\text { Land unit is almost favourable for coffee tree and } \\
\text { there are few limitations of ecological } \\
\text { requirements }\end{array}$ & $60-80$ \\
\hline $\begin{array}{l}\text { PI } 3 \text { : Potential index } 3 \\
\text { (marginally suitable) }\end{array}$ & $\begin{array}{l}\text { Land unit is marginally desirable for coffee tree } \\
\text { and there are severe limitations of ecological } \\
\text { requirements }\end{array}$ & $30-60$ \\
\hline $\begin{array}{l}\mathbf{N}: \text { Not potential index } \\
\text { (unsuitable) }\end{array}$ & $\begin{array}{l}\text { Land unit is almost unfavourable for coffee tree } \\
\text { and there are severe limitations }\end{array}$ & $<30$ \\
\hline
\end{tabular}




\section{Result and discussion}

\subsection{The environmental factors were used in the process}

Table 3. The environmental factors were involved in the process

\begin{tabular}{|c|c|c|c|c|c|c|}
\hline Factors & Sub-factors & $\mathbf{P I}_{1}$ & $\mathbf{P I}_{2}$ & $\mathbf{P I}_{3}$ & $\mathbf{N}$ & $\mathbf{W}$ \\
\hline \multirow{3}{*}{$\begin{array}{c}\mathbf{F}_{\mathbf{1}}: \\
\text { Temperature }\left({ }^{0}\right. \\
\text { C) }\end{array}$} & $\begin{array}{l}\mathrm{SF}_{1} \text { : Average annual } \\
\text { temperature }\end{array}$ & $>25$ & $\begin{array}{c}>22- \\
25\end{array}$ & $18-22$ & $<18$ & 0.03 \\
\hline & $\begin{array}{l}\mathrm{SF}_{2} \text { : Annual average } \\
\text { minimum temperature }\end{array}$ & $>20$ & $17-20$ & $14-<17$ & $<14$ & 0.03 \\
\hline & $\begin{array}{l}\mathrm{SF}_{3} \text { : Annual average } \\
\text { maximum temperature }\end{array}$ & $>30$ & $27-30$ & $22-27$ & $<22$ & 0.03 \\
\hline $\begin{array}{l}\mathbf{F}_{2}: \\
\text { Total annual } \\
\text { precipitation } \\
(\mathrm{mm})\end{array}$ & $\begin{array}{l}\mathrm{SF}_{4}: \text { Total annual } \\
\text { precipitation }(\mathrm{mm})\end{array}$ & $>2500$ & $\begin{array}{c}2100- \\
2500\end{array}$ & $\begin{array}{c}1300- \\
2100\end{array}$ & $<1300$ & 0.08 \\
\hline $\begin{array}{c}\mathbf{F}_{3} \text { : } \\
\text { Number of dry } \\
\text { months / year } \\
\text { (month) }\end{array}$ & $\begin{array}{l}\text { SF }_{5} \text { : Number of dry months } \\
\text { year (month) }\end{array}$ & $<2$ & 3 & $>3-4$ & $>4$ & 0.03 \\
\hline \multirow{5}{*}{$\begin{array}{c}\mathbf{F}_{4} \text { : } \\
\text { Soil } \\
\text { characteristics }\end{array}$} & SF $_{6}$ Soil type & $\begin{array}{l}\mathrm{Ft}, \mathrm{Fk} \\
\mathrm{Fu}\end{array}$ & $\begin{array}{l}\text { Fv, Fn, } \\
\text { Fe, Fs }\end{array}$ & $\begin{array}{l}\text { Fp, Fq, } \\
\text { Fa, Hs }\end{array}$ & Other & 0.24 \\
\hline & $\mathrm{SF}_{7}$ : Slope (degree) & $<3$ & $>3-8$ & $>8-15$ & $>15$ & 0.05 \\
\hline & SF 8: Soil depth (cm) & $>100$ & $\begin{array}{l}>70- \\
100\end{array}$ & $>50-70$ & $<50$ & 0.05 \\
\hline & SF9: Rock exposed above soil & Never & $\begin{array}{l}\text { Neglig } \\
\text { ibility }\end{array}$ & $\begin{array}{c}\text { Fragmen } \\
\mathrm{t}\end{array}$ & $\begin{array}{l}\text { Cluster } \\
\text { structu } \\
\text { re }\end{array}$ & 0.05 \\
\hline & SF 10: Soil composition & $\begin{array}{l}\text { Loam, } \\
\text { Clay }\end{array}$ & $\begin{array}{l}\text { Clay } \\
\text { loam }\end{array}$ & $\begin{array}{l}\text { Sandy } \\
\text { loam }\end{array}$ & $\begin{array}{l}\text { Sand, } \\
\text { Loamy } \\
\text { sand }\end{array}$ & 0.06 \\
\hline $\begin{array}{l}\mathbf{F}_{5}: \\
\text { Flood status }\end{array}$ & $\mathrm{SF}_{11:}$ Flood status & Never & $\begin{array}{l}\text { Neglig } \\
\text { ibility }\end{array}$ & $\begin{array}{c}\text { Flooding } \\
\text { depth in } \\
\text { average } \\
\text { of } 30 \\
\mathrm{~cm} \\
\text { frequentl } \\
\mathrm{y}\end{array}$ & $\begin{array}{l}\text { River } \\
\text { or } \\
\text { stream }\end{array}$ & 0.03 \\
\hline $\begin{array}{c}\mathbf{F}_{\mathbf{6}} \text { : } \\
\text { Irrigation } \\
\text { system }\end{array}$ & $\mathrm{SF}_{12 \text { : Irrigation system }}$ & $\begin{array}{l}\text { Ability } \\
\text { to } \\
\text { actively } \\
\text { water } \\
\text { irrigation } \\
\text { system } \\
\end{array}$ & $\begin{array}{l}\text { Semi- } \\
\text { active } \\
\text { water } \\
\text { irrigati } \\
\text { on } \\
\text { system }\end{array}$ & $\begin{array}{l}\text { Irrigatio } \\
\text { n system } \\
\text { is hardly }\end{array}$ & $\begin{array}{l}\text { No } \\
\text { irrigati } \\
\text { on } \\
\text { system }\end{array}$ & 0.15 \\
\hline $\begin{array}{c}\mathbf{F}_{7} \text { : } \\
\text { Currently land } \\
\text { unit } \\
\end{array}$ & $\begin{array}{l}\text { SF13: Land units with current } \\
\text { land use }\end{array}$ & Perennials & $\begin{array}{l}\text { Annua } \\
\text { l crops }\end{array}$ & $\begin{array}{l}\text { Unused } \\
\text { land }\end{array}$ & Others & 0.17 \\
\hline
\end{tabular}


According to Instruction for agricultural production land evaluation [21], a focus group discussion was implemented to weight the important of 13 sub-factors were used in process. Soil type play the important role to impact on growing the plants $\left(\mathrm{SF}_{6}\right.$ : 0.24$)$, followed by land units with current land use $\left(\mathrm{SF}_{13}\right.$ : 0.17$)$ (Table 3). Use of weighted overlay the maps of 13 sub-factors provided the potential map. Land potential map for coffee tree based on environmental factors showed in Fig 2. This result showed the northern of commune were the most suitable site in study area. Sub-factors ( $\mathrm{SF}_{9}$ : rock exposed above soil; $\mathrm{SF}_{11}$ : flood status, $\mathrm{SF}_{12}$ irrigation system) have the largest "potential” land for coffee plants, while the sub-factors $\left(\mathrm{SF}_{1}\right.$ : average annual temperature, $\mathrm{SF}_{2}$ : annual average minimum temperature, $\mathrm{SF}_{4}$ : total annual precipitation, $\mathrm{SF}_{8:}$ soil depth, $\mathrm{SF}_{10}$ : soil composition) with the smallest potential land.

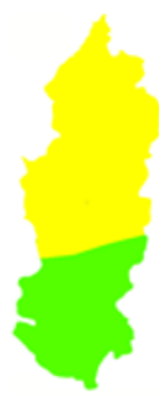

$\mathrm{SF}_{1}$

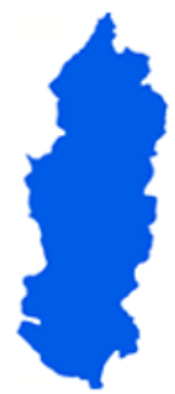

$\mathrm{SF9}$

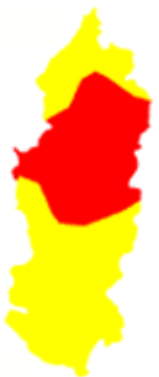

$\mathrm{SF}_{2}$

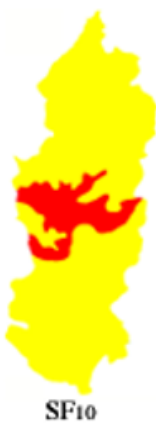

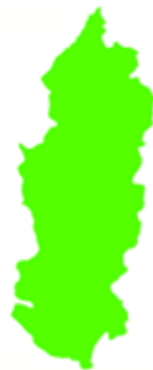

$\mathrm{SF}_{3}$

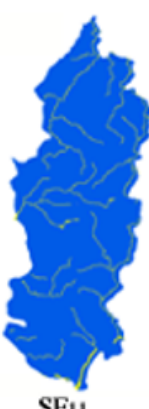

$\mathrm{SF}_{11}$

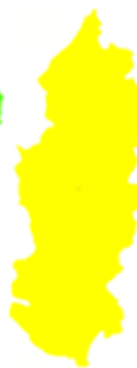

$\mathrm{SF}_{4}$

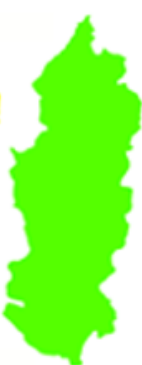

SF5

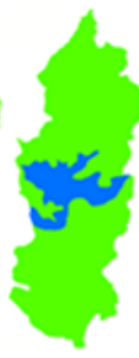

SF6

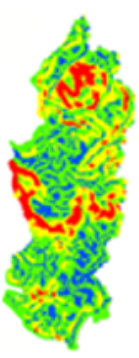

$\mathrm{SP} 7$

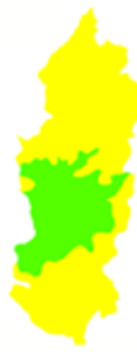

SF8

Fig. 2. Evaluation land potential for each sub-factor of buffer zone of Ta Dung Nature park, Dak Som commune

\subsection{Analysis of Remote Sensing Image Data}

Fig 3 showed the current coffee areas $\left(24 \mathrm{~km}^{2}\right)$ using the analysis of Remote Sensing Image Data, that result also showed the people have focused on changing crops in response to require development of economy. Evaluation potential land (Fig. 3a) had high accuracy compare with the analysis of Remote Sensing Image Data (Fig. 3b). The coffee areas increased about 1000 ha, especially in the northern site since 2014. That also reflects survey results, the commune's poverty rate was decreased during 10 years. 


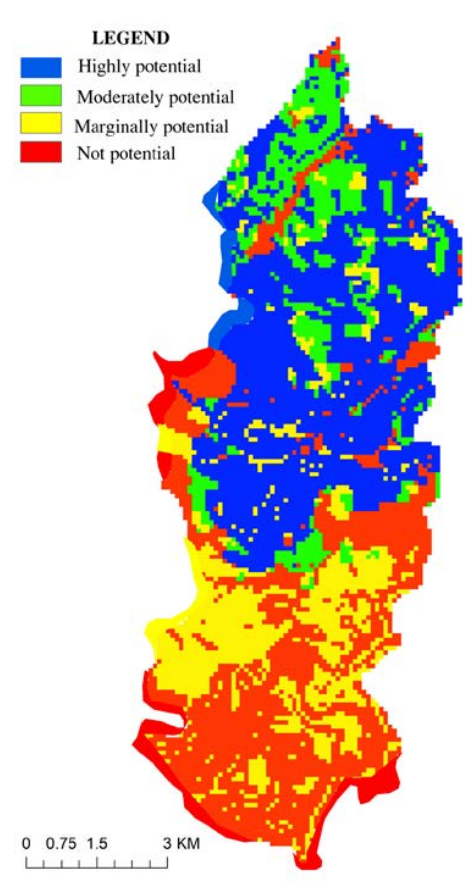

(a)

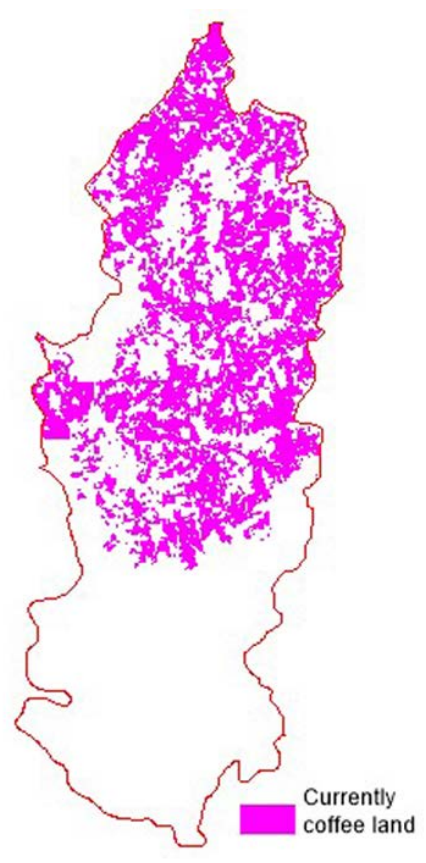

(b)

Fig. 3. (a) Potential land for coffee plants; (b) Current coffee land

\subsection{Proposal land for coffee plants}

The results of classification showed there is a close correspondence between the patterns of the potential areas for the cultivation of coffee with current coffee areas. Fig 4 showed the map for a proposal the land for coffee plants after overlay the high potential land and current coffee areas. Potential land for coffee plants (AHP-GIS methodology) with 29,24 km² (38,03\% total study area). Current coffee area (RS methodology) with 24,00 $\mathrm{km}^{2}$ (31,21\% total study area) (Table 4). The final map (Fig 4b) provided a proposal land for coffee plants with $5,24 \mathrm{~km}^{2}$ (6,82\% total study area). The land potential of the study area should be further explored by the possibility of expanding cultivated area. On the other hand, the areas of coffee planted on the land that is not in the most suitable is about $5 \%$. This is a remarkable finding of this study which explains the fact that the coffee fields do not have the desired results in few areas.

Table 4. Potential model for coffee plantation and area of proposal for coffee plants in buffer zone of Ta Dung Nature park

\begin{tabular}{|c|c|c|c|c|c|c|}
\hline Methodology & \multicolumn{2}{|c|}{ AHP-GIS } & \multicolumn{2}{|c|}{ RS } & \multicolumn{2}{c|}{ AHP-GIS-RS } \\
\hline Result & \multicolumn{2}{|c|}{$\begin{array}{c}\text { Potential land for } \\
\text { coffee plants }\end{array}$} & \multicolumn{2}{|c|}{ Current coffee area } & \multicolumn{2}{c|}{$\begin{array}{c}\text { Proposal land for coffee } \\
\text { plants }\end{array}$} \\
\hline Unit & $\left(\mathrm{km}^{2}\right)$ & $(\%)$ & $\left(\mathrm{km}^{2}\right)$ & $(\%)$ & $\left(\mathrm{km}^{2}\right)$ & $(\%)$ \\
\hline Value & 29,24 & 38,03 & 24,00 & 31,21 & 5,24 & 6,82 \\
\hline
\end{tabular}




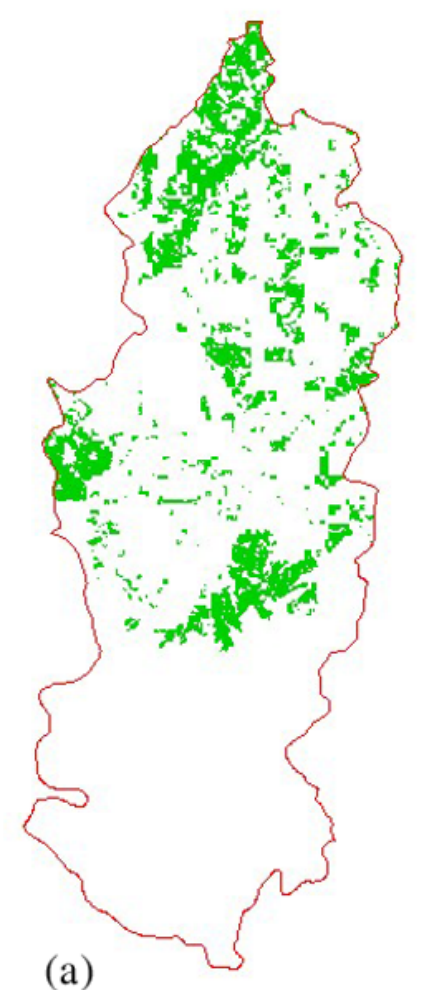

(a)

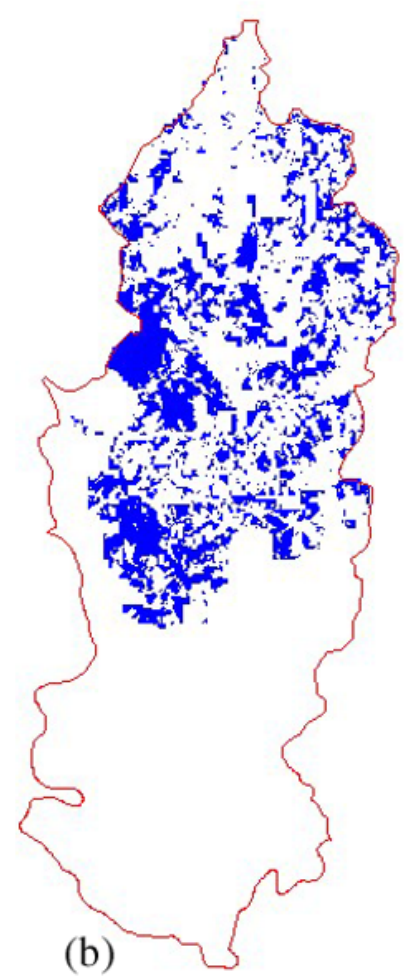

(b)

Fig. 4. (a) Coffee plantation not in high suitable areas; (b) Proposal for extend coffee plants

\section{Conclusion}

Study area was a case of a commune of buffer zone of Ta Dung Nature park, Vietnam. Proper planning and direction in agriculture and forestry play an important role in protected forest management. The result showed the most important criteria are soil type (0.24), followed by land use cover unit $(0.17)$ and irrigation system (0.15) play the role on the growing of coffee plants in the region. Sub-factors $\left(\mathrm{SF}_{9}\right.$ : rock exposed above soil; $\mathrm{SF}_{11}$ : flood status, $\mathrm{SF}_{12}$ : irrigation system) have the largest "potential" land for coffee plants, while the sub-factors $\left(\mathrm{SF}_{1}\right.$ : average annual temperature, $\mathrm{SF}_{2}$ : annual average minimum temperature, $\mathrm{SF}_{4}$ : total annual precipitation, $\mathrm{SF}_{8:}$ soil depth, $\mathrm{SF}_{10}$ : soil composition) with the smallest potential land. It is recommended to orient coffee plantation in 6,82 \% total of study area which in other landuse has high suitability for coffee. An approach based on the techniques mentioned above allowed the proper identification of areas with potential for coffee plants in buffer area of Ta Dung Nature park that aims to help the decision manager in making the proper plan. By other hand, a framework of potential model was provided for other industry crops in other study areas in Vietnam. In addition, safe farming practices and protection of the soil environment need to be further studied because of the high impact of soil resources on plant growth. Research focused on evaluation of soil physical properties instead of chemical properties because they can be improved by fertilizers

The study was supported by The Project E 1.2 by Vietnam - Russia Tropical Centre (63 Nguyen Van Huyen street, Ha Noi, Vietnam) for 2021 (study area: Ta Dung Nature Park and its buffer zone, a case study of Dak Som commune) . We are grateful to Institute of Tropical Ecology of Vietnam - Russia Tropical Centre for their support during survey. 


\section{References}

1. General Statistics Office. Statistical Yearbook of Dak Nong Province (2019)

2. T.M.N. Bui. Economic \& Policies, 8, 157-164 (2019)

3. T.D. Phan. Ho Chi Minh National University, Vietnam (2017)

4. T.T.H. Tran. Hanoi National University, Vietnam (2018)

5. Y. Pham, K. Reardon-Smith, S. Mushtaq, G. Cockfield. Clim, Chang, 156, 609-630 (2019)

6. N. Arizpe, R. Orellana, E. Conde, J. Hernández, M. Villers. Interciencia, 34, 322-329 (2009)

7. J. Jaramillo, A. Chabi-Olaye, C. Kamonjo, A. Jaramillo, F.E. Vega, H.M. Poehling, C. Borgemeister. PLoS ONE, 4, e6487 (2009)

8. S.A. Rojas, U.K. Hartman, M.R. Almonacid. Ambient. Desarro, 16, 93-104 (2012)

9. H.Q. Nguyen. Vietnam Journal of Social Science, 6,62-69 (2015)

10. B.N. Nguyen, Q.T. Nguyen, W.D. Sunderlin, Y. Yurdi. Regional community forestry training center for Asia and the Pacific (RECOFTC), Bangkok, Thailand (2009)

11. FAO. http.//www.fao.org/docrep/t0715e/ t0715e06.htm. Accessed November 10, 2017. (1976).

12. FAO. Food and Agriculture Organization of the United Nations (1984)

13. T.L. Saaty. Agricultural Economics Review, 70 (1980)

14. T.L. Saaty. J. Math, Psychol, 15, 234-281 (1977)

15. R.W. Saaty. Math, Model, 9, 161-176 (1987)

16. E.H. Forman. Springer, Berlin, Heidelberg, 295-318 (1990)

17. L. Lara Estrada, L. Rasche, U.A. Schneider. Model, Softw, 95, 196-209 (2017)

18. M.A. Mighty. Appl, Geogr, 58, 84-93 (2015)

19. M.A. Arango-Argoti. Master's Thesis, Department of Crops and Agro-Environmental Sciences, College of Agricultural Sciences, Universidad de Puerto Rico, Recinto de Mayagüez (RUM), Mayagüez, Puerto Rico (2007)

20. H.A. González, J.R. Hernández Santana. Investig, Geogr, 2016, 105-118 (2016)

21. Ministry of Science and Technology of Vietnam. Instruction for agricultural production land evaluation of Vietnamese Standard TCVN 8409:2012 (2012)

22. M.S. Hossain, N.G. Das. Comput, Electron, Agric, 70, 172-186 (2010)

23. O. Dengiz, C. Gol, F.E. Sario Lu. S. Edi. African Journal of Agricultural Research, 5(12), 1482-1496 (2010) 